\title{
FORMULATION OF ORALLY DISINTEGRATING SECANG (CAESALPINIA SAPPAN L.) TABLETS AS AN ANTIOXIDANT WITH HYDROXYPROPYL CELLULOSE AS A MASKING AGENT
}

\author{
RESMI MUSTARICHIE ${ }^{a^{*}}$, DRADJAD PRIAMBODOb
}

aDepartment of Pharmaceutical Analysis and Medicinal Chemistry, Faculty of Pharmacy, Universitas Padjadjaran, Indonesia, bepartment of Pharmaceutics (Apothecary Programme), Faculty of Pharmacy, Universitas Padjadjaran

Email: resmi.mustarichie@unpad.ac.id

Received: 18 Feb 2019, Revised and Accepted: 10 May 2019

ABSTRACT

Objective: The objective of this research was to formulate Orally Disintegrating Tablets (ODT) preparations for secang (Caesalpinia sappan L.) wood extract as antioxidants that met the requirements as a pharmaceutical preparation.

Methods: Three ODT formulas were made using the composition of the extract of secang wood, HPC-H, kollidon $®$ CL, Avicel $₫$ PH 101, mannitol, acesulfame, magnesium stearate, citric acid, and menthol. The bitter taste of the extract of wood secang was covered with the Hydroxy Propyl Cellulose High Substitution (HPC-H) masking agent. Variations in HPC-H concentration were 4\%, 4.5\%, and 5\%. The evaluation of tablet print mass tested included water content, flow velocity, and resting angle, real density, incompressible density, and compressibility. Evaluation of tablets tested included weight uniformity, uniformity of size, hardness, friability, and disintegration time. The tablet antioxidant activity testing was carried out by the Diphenylpicylhydrazyl (DPPH) method.

Results: The results showed that all ODT formulas of secang wood extract were fulfilling the requirements as a tablet preparation according to Indonesian Pharmacopoeia IV. IC 50 values obtained from antioxidant testing on the three ODT formulas for a secang wood extract for formula I was $3.614 \mathrm{ppm}$, formula II was $3.464 \mathrm{ppm}$, formula III was $3.173 \mathrm{ppm}$, and the wood extract was $3.757 \mathrm{ppm}$.

Conclusion: The results obtained in this research work clearly indicated ODT formulas of secang wood extract fulfilled Indonesian Pharmacopea IV requirement and belong to the category of very strong antioxidants because they have an $\mathrm{IC}_{50}$ value of less than 50 ppm.

Keywords: Secang wood, Caesalpinia sappan, Antioxidant, Orally Disintegrating Tablets (ODT), DPPH

(C) 2019 The Authors. Published by Innovare Academic Sciences Pvt Ltd. This is an open-access article under the CC BY license (http://creativecommons.org/licenses/by/4.0// DOI: http://dx.doi.org/10.22159/ijap.2019v11i4.32663

\section{INTRODUCTION}

The production of free radicals in the body continues to increase due to external influences, such as cigarette smoke, vehicle fumes, toxins, and solar radiation so that the body's antioxidant defense system no longer works effectively to protect the body from free radical attacks. Free radicals can cause oxidative stress. Prevention can be done by administering exogenous antioxidants. Antioxidants are compounds that can react with free radicals and function to neutralize free radicals $[1,2]$. One test of antioxidant activity was carried out by testing Diphenylpicrylhidrazy (DPPH) free radical trapping [3]

Sappan wood or Kayu secang (Indonesian) is reported of having medicinal properties, such as natural antioxidant, relieve vomiting of blood, and mix of ingredients for malaria drugs [4]. Indonesian people have used a lot of secang wood as traditional medicine [5]. Secang wood contains gallic acid, tannin, resin, resorcin, brazilin, brazilein, d-alpha-phellandrene, ocimene, essential oil [6]. The use of secang in the community is still limited in the form of steeping [7]. In this research, the formulation of Orally Disintegrating Tablets (ODT) extract of secang wood using Hydroxy Propyl Cellulose (HPC-H) as a masking agent to cover the bitter taste of secang wood extract as an active ingredient with the method of making direct press tablets. This is because the ODT drug will dissolve or disintegrate in the mouth when in contact with saliva in less than 60 seconds [8].

In the previous study, secang ethanol extract and secang wood extract fraction had activities as antioxidants and the results of the tests showed that the greater the concentration of the test solution, the smaller the DPPH absorbance produced $[9,10]$.

This study reports the formulation of orally disintegrating secang tablets as an antioxidant with hydroxyl propyl cellulose as a masking agent. The results of this study are expected to add alternatives to well-known antioxidants in the market including enzymes and other substances, such as vitamin C, vitamin E, and beta carotene. So far there has been no publication about ODT which is efficacious as an antioxidant from secang.

\section{MATERIALS AND METHODS}

\section{Materials}

The secang wood chips were obtained from the Manoko Experimental Garden, Lembang, West Java and determined at the Laboratory of Taxonomy, Biology Department, Faculty of Mathematics and Natural Sciences, Universitas Padjadjaran. Its plant identification sheet no. 425/HB/02/2018 showed that the plant was Caesalpinia sappan L., Family: Fabaceae.

\section{Chemicals}

HPC-H (Nippon Soda Co., Ltd), Kollidon® CL (Sigma-Aldrich), Avicel® PH 101 (Sigma-Aldrich), Mannitol (Sigma-Aldrich), Acesulfame (Sigma-Aldrich), Magnesium Stearate (Sigma-Aldrich), Citric acid (Sigma-Aldrich), Menthol (Sigma-Aldrich), Acetosal (Sigma-Aldrich), DPPH (1,1-diphenyl-2-picrylhydrazyl) (Sigma-Aldrich). All chemicals used for the formulation were Pharmaceutical grade. DPPH $(1,1-$ diphenyl-2-picrylhydrazyl) and Vitamin C were Analytical grades.

Methods

\section{Extractions}

Fresh secang wood was washed and dried by aerating at room temperature and protected from sunlight. It was chopped and blended until it became powder. The 3,000-gram powder was extracted using the maceration method using 96\% ethanol as its solvent based on modification method of Kusuma et al. [11]. The extract was concentrated using a rotary evaporator at a temperature of $40-50{ }^{\circ} \mathrm{C}$ and continued by using a water bath at a temperature of $40-50{ }^{\circ} \mathrm{C}$ to obtain a dry extract with a constant weight.

\section{Phytochemical screening}

Phytochemical screening was carried out to determine the content of secondary metabolites in alkaloids, tannins, polyphenols, flavonoids, steroids, triterpenoids, quinones, saponins, monoterpenoids, and 
sesquiterpenoids in secang wood and its extract guidance by Farnsworth method [12]

\section{Standardization of extracts}

Standardization of wood extract was carried out to ascertain water content, drying losses, levels of soluble ethanol extracts, levels of. Water-soluble extracts, total ash content, acid insoluble ash content and metal content of extracts guided by the Indonesian Pharmacopeia 4th edition [13]

\section{ODT formulation}

In this study, three formulas were made using the composition of the extract of secang wood, HPC-H, kollidon ${ }^{\circledR}$ CL, Avicel® PH 101, mannitol, acesulfame, magnesium stearate, citric acid, and menthol. Tablet formulations can be seen in table 1. Formulation testing referred to other ODT tablet published by Liang and Chen [14]. Tablet evaluation included weight uniformity, uniformity of size, uniformity of hardness, fragility (friability), and disintegration time [15].

Table 1: ODT secang wood extract formula

\begin{tabular}{|c|c|c|c|}
\hline \multirow[t]{2}{*}{ Composition } & \multicolumn{3}{|c|}{ Formula (mg) } \\
\hline & F1 & F2 & F3 \\
\hline Secang wood extract & 100.00 & 100.00 & 100.00 \\
\hline $\mathrm{HPC}-\mathrm{H}$ & 20.00 & 22,50 & 25.00 \\
\hline Kollidon ${ }^{\circledR}$ CL & 20.00 & 20.00 & 20.00 \\
\hline Avicel ${ }^{\circledR} \mathrm{PH} 101$ & 237.25 & 234.75 & 232.25 \\
\hline Mannitol & 90.00 & 90.00 & 90.00 \\
\hline Acesulfame & 15.00 & 15.00 & 15.00 \\
\hline Magnesium Stearate & 10.00 & 10.00 & 10.00 \\
\hline Citric acid & 7.50 & 7.50 & 7.50 \\
\hline Menthol & 0.25 & $0 ., 25$ & 0.25 \\
\hline Total & 500.00 & 500.00 & 500.00 \\
\hline
\end{tabular}

\section{Antioxidant activity measurement}

The antioxidant activity test was determined by the UV-visible spectrophotometric method using DPPH (1, 1-diphenyl-2-picrylhydrazyl) reagent by looking at the absorbance of the secang wood extract in the extract and in ODT. Vitamin C was used to control positive. This method was similar to other published works [16-18] and prepared with the following: making a secang wood extract solution, making DPPH solution, determination of the maximum wavelength of DPPH, determination of DPPH operating time, determination of operating time DPPH with extract, testing the antioxidant activity of extracts and ODT of secang wood extract. The blank used was the extract solution and the solution of each formula with the same concentration. The antioxidant activity of the test solution was calculated by the following formula:

$$
\% \text { inhibition }=\left[1-\left(A_{\text {test }} / A_{\text {control }}\right)\right] \times 100 \%
$$

The $\mathrm{IC}_{50}$ value was calculated from the linear regression curve between the percent inhibition of absorbance to the concentration of extract and ODT of secang wood extract.

\section{Hedonic taste}

The hedonic test [19] was carried out on 30 panelists taken randomly. Panelists were asked to taste one ODT extract of wood extract from each formula, then asked for a response and assessment of the tablet through a given questionnaire, including the level of preference for the tablet, preference for taste, preference for after taste, and preference for the level of irritation. Data analysis: carried out using the Newman-Keuls statistical test.

\section{RESULTS AND DISCUSSION}

\section{Extraction results}

The extracted results obtained a dry extract with a yield of $8 \% \mathrm{w} / \mathrm{w}$ and the results of observations of organoleptic secang wood extract were in the form of dry powder, brownish red, smelly, and distinctive taste.

\section{Phytochemical screening}

Phytochemical screening results can be seen in table 2 .

Table 2: Secondary metabolites of Caesalpinia sappan

\begin{tabular}{|c|c|c|c|}
\hline No & Secondary metabolites & Wood sample & Extract \\
\hline 1 & Alkaloids & + & + \\
\hline 2 & Flavonoids & + & + \\
\hline 3 & Quinine & + & + \\
\hline 4 & Monoterpenoids and Sesquiterpenoids & + & + \\
\hline 5 & Polyphenol & + & + \\
\hline 6 & Saponins & - & - \\
\hline 7 & Steroids and Triterpenoid & - & - \\
\hline 8 & Tannin & + & + \\
\hline
\end{tabular}

Notes: += detected; -= not detected

Chandra [20] reported that C. sappan showed the presence of flavonoids, phenolic compounds, tannins, saponin, protein, oxalic acid, carbonate, oil, and fat. Preliminary phytochemical screening of C. sappan leaves showed the presence of carbohydrates, glycosides, flavonoids, phenols, tannins and amino acids in the crude drug was reported by Kaur et. al [21]. Srinivasan et. al [22] in their preliminary phytochemical analyses showed the presence of steroids, tannin, phenol, saponins, and flavonoids in the ethanolic extract. This slight difference in phytochemical screening results was most likely due to the origin of the sample.

\section{Standardization of extracts}

To find out the quality of the secang wood extract used more clearly can be seen in table 3 . 
Table 3: Results of standardization of extracts

\begin{tabular}{lll}
\hline Tests & Concentration (\%) & Concentration based on indonesian herbal pharmacopeia (\%) [23] \\
\hline Water-soluble extractive & $19.5 \pm 0.76376$ & - \\
Ethanol soluble extractive & $40.5 \pm 0,076376$ & - \\
Water content & $0.5 \pm 0.05$ & $<10$ \\
Drying shrinkage & $0.5 \pm 0.05$ & - \\
Total ash content & $9.22 \pm 0,251661$ & $<1.4$ \\
Acid-insoluble ash content & $4.56 \pm 0.3$ & $<0.6$ \\
\hline
\end{tabular}

From the results of standardization of extracts that had been done, it was found all parameters fulfilled the concentration described in Indonesian Herbal Pharmacopeia. Actually, provisions regarding the need for standardization of extracts from herbal ingredients are also required by BBOT (Traditional Medicine Raw Materials) [24] and WHO [25]. The water content obtained at $0.5 \%$ meaning it could reduce the risk of damage to secang wood extract due to the growth of fungi and bacteria. In addition, the value of water content was also related to the dosage on the preparation because the extract with a high value of the water content, the amount of extract needed to reach the desired dosage on more preparations. The results obtained from testing drying losses were $0.5 \%$. It indicated that the compounds in the secang wood extract were only lost or evaporated as much as $0.5 \%$ during the heating process. The results of total ash content determination were $9.22 \%$ and the results of the determination of acid insoluble ash content were $4.56 \%$. These results were not in accordance with the standards listed in Herbal Pharmacopoeia. This was possibly due to metal or mineral contamination during planting due to environmental factors. From the results of metal assays using Shimadzu AA7000 that had been carried out, it was obtained that the metal content of $\mathrm{Hg}$ and $\mathrm{Pb}$ was $0.024 \mu \mathrm{g} / \mathrm{kg}$ and $13.72 \mathrm{mg} / \mathrm{kg}$, and the $\mathrm{Sn}, \mathrm{Cd}$, and As metals obtained did not show the detection of the three metals in the extract sappan wood. The value of $\mathrm{Hg}$ metal detected in the secang wood extract was still below the limit stated in the Indonesian National Standard in 2009, which is equal to $0.1 \mathrm{mg} / \mathrm{kg}$. Meanwhile, the value of the $\mathrm{Pb}$ metal levels detected in the extract of secang wood was above the limit stated in the Indonesian National Standard in 2009 [26], which was $7.0 \mathrm{mg} / \mathrm{kg}$. The high value of $\mathrm{Pb}$ metal content detected in the wood extract was caused by environmental influences.

\section{Formulation}

In the research that had been done, ODT secang wood extract was made in 3 formulations with different concentrations in the masking agent, namely HPC-H with a concentration variation of $4.0 \%, 4.5 \%$, and $5.0 \%$. (see table 1). The composition considerations were designed based on the following considerations. High Viscosity Grade of Hydroxypropyl Cellulose (HPC-H) was thought as an effective controlled release (CR) material since it was a hydrophilic polymer. It was for hydrophilic matrix and sustained release formulation [27]. It dissolved in water and organic solvents, at room temperature, inert with regarded to the active ingredients (API), improved the hardness of the tablet, optimized disintegration of the tablet, was soluble in aqueous mediums and $100 \%$ ethanol. Due to the balance of strong disintegration and optimal surface homogeneity, our cross-povidone Kollidon ${ }^{\circledR}$ CL-F was our first choice tablet disintegrant. The super-disintegrant was specifically suitable for use in small tablets to fasten disintegration and dissolution. Kollidon ${ }^{\circledR}$ CL-F could also be used in wet granulation processes when a large number of granulation liquids were needed [28]. Avicel ${ }^{\circledR}$ PH 101 was used as a disintegrating agent [29]. Mannitol [30] was a polyol (sugar alcohol) and an isomer of sorbitol. Mannitol $(\mathrm{C} 6 \mathrm{H} 8(\mathrm{OH}) 6)$ was used in pharmaceutical products as a sweetening agent, tablet and capsule diluent, excipient for chewable tablets, a tonicity agent, and as a vehicle (bulking agent) for lyophilized preparations. Acesulfame potassium was often used in sweetener blends to produce a more sugar-like taste in a food or beverage. The ingredient also helped the blend retain its sweetness during baking or heat processing, which was important for preparing foods, such as cookies and candies [31]. Magnesium stearate was a fine white powder. Its main purpose was providing a lubricant for capsules and tablets. It increased flowability, which ensured efficiency through the manufacturing process [32]. Citric Acid Used in Food. About 50 percent of the world's citric acid production was used as a flavor enhancer in beverages. Citric acid created a slightly tart, refreshing flavor and balances the sweetness in sodas, teas, juices, and other drinks. The acidic $\mathrm{pH}$ of citric acid also made it useful as a preservative [33]. Menthol was alcohol produced from mint oils or prepared synthetically. When added to pharmaceuticals and foods, menthol functions as a fortifier for peppermint flavors. It also had a counterirritant effect on skin and mucous membranes, thereby producing a local analgesic or anesthetic effect [34].

\section{Print process in process control (IPC)}

To find out the nature of the substance to be printed, IPC was tested for print mass. This test was intended to determine whether the print mass was feasible or not so that this test could be used as a supporting factor to determine the quality of the tablet. To be more clear, it can be seen in table 4 .

Table 4: Print mass evaluation results

\begin{tabular}{lllll}
\hline Parameter & Formula 1 & Formula 2 & Formula 3 & Requirement [35] \\
\hline Drying Loss (\%) & $1.490 \pm 0.235$ & $1.453 \pm 0.130$ & $1.630 \pm 0.145$ & $<2$ \\
Flow Rate (g/s) & $11.817 \pm 0.339$ & $11.681 \pm 1.679$ & $11.586 \pm 0.554$ & $>10$ \\
Break Angle (0) & $21.022 \pm 0.500$ & $22.906 \pm 1.132$ & $20.580 \pm 1.446$ & $<25$ \\
Real Density (g/ml) & $0.433 \pm 0.003$ & $0.442 \pm 0.002$ & $0.480 \pm 0.003$ & - \\
Compressible density (g/ml) & $0.517 \pm 0.008$ & $0.519 \pm 0.007$ & $0.568 \pm 0.005$ & - \\
Compressibility (\%) & $16.228 \pm 1.049$ & $14.948 \pm 0.963$ & $15.542 \pm 0.077$ & $<20$ \\
\hline
\end{tabular}

From the results of testing for shrinkage drying, all formulas met the requirements. The results of the drying shrinkage test could affect the powder flow rate because it related to the moisture from the tablet print mass. If the tablet's print mass had high humidity, it would affect the tablet printing process by sticking the tablet to the punch, also that the tablet produced was more fragile From the results of testing the flow rate that had been done, the flow properties of all formulas were good because they were more than $10 \mathrm{~g} / \mathrm{s}$ [35]. This was related to the tablet printing process. The better the mass flow rate of the print, the easier the mass could flow when printing tablets. Tests for resting angles were also carried out from data obtained after flow rate testing was carried out. The results of the resting angle test obtained from all formulas were very good because the values show less than 250 [35]. The greater the value of the resting angle, the worse the print mass flow. This could cause unevenness in the weight of tablets produced. From the results of compressibility testing that had been done on all formulas, the value of compressibility was good because it was less than $20 \%$. Based on the results of compressibility testing that had been done it could be concluded that the process of compressing the print mass could be done because of the nature of the flow of powder and the ability of the print mass to form a preparation would be stable and compact when given pressure. 


\section{ODT quality control (QC)}

After the process of evaluating the print mass, the printed mass of the tablet was made using the direct press method. The tablets produced were evaluated according to the requirements of the Indonesian Pharmacopoeia IV Tablet evaluation included weight uniformity, uniformity of size, uniformity of hardness, fragility (friability), and disintegration time can be seen in table 5 .

Table 5: ODT quality control

\begin{tabular}{lll}
\hline Parameter & F1 & F2 \\
\hline Weight (mg) & $506.65 \pm 7.345$ & $516.17 \pm 5.896$ \\
Diameter (mm) & $12.1375 \pm 0.036$ & $12.1605 \pm 0.013$ \\
Thickness (mm) & $5.2260 \pm 0.037$ & $5.3125 \pm 0.077$ \\
Hardness (N) & $53.3 \pm 6.672$ & $49.125 \pm 5.458$ \\
Friability (\%) & $0.324 \pm 0.163$ & $0.577 \pm 0 / 324$ \\
Disintegration Time (seconds) & $30.667 \pm 6.506$ & $26.667 \pm 3.512$ \\
\hline
\end{tabular}

From the results of testing the weight uniformity of tablets that had been done, the results of each formula had met the requirements stated in Pharmacopoeia Indonesia IV because the weight of the tablet did not deviate from 5\%. In addition, uniformity of tablet size was measured, i. e the diameter and thickness of the tablet. The results obtained from tablet size uniformity testing met the requirements stated in Indonesian Pharmacopoeia III [36], that the tablet diameter should not be more than 3 times and not less than 1, 3 thick tablets. Then the tablet hardness test was carried out to determine the resistance of the tablet to shock and pressure. The hardness of the tablet is directly proportional to the disintegration time, ie the smaller the hardness, the faster the disintegration time. The results obtained from tablet hardness testing on all formulas had an average value ranging from 40,875-53,300 N. In addition, tablet reliability testing and disintegration testing on all tablet formulas were carried out. From the results of testing the tablet reliability, the results of all formulas had met the requirements. This meant that the friability values of all formulas indicated that tablets had good friability and were resistant to damage in packaging, packaging, and distribution. From the results of testing the disintegration time that had been done, all formulas had a disintegration time that was in accordance with FDA [37] requirements, namely the ODT dosage form has a very fast disintegration time, i. e no more than 60 seconds.

\section{Results of the antioxidant activity}

Antioxidant activity test was carried out to determine the antioxidant activity in secang wood extract and on ODT extract of secang wood extract. The antioxidant activity test was carried out by determining the $50 \%$ inhibitory concentration $\left(\mathrm{IC}_{50}\right)$ from the secang wood extract and ODT preparation for secang wood extract using the DPPH (1,1-diphenyl2-picrylhydrazyl) method with a UV-Visible spectrophotometer. In this study, vitamin C was used as a comparative antioxidant.

\section{Antioxidant activity}

In this test, the antioxidant activity of ODT extract of secang wood was tested. Each ODT formula contains $100 \mathrm{mg}$ of secang wood extract. The test solution was made by weighing one tablet from each formula and dissolved in $100 \mathrm{ml}$ of $96 \%$ ethanol so that the solution concentration of $1000 \mathrm{ppm}$ was obtained. After that, the solution was centrifuged to separate the extract from the tablet filling component. The supernatant obtained was then diluted to a concentration of $20 \mathrm{ppm}$. After that, multilevel dilution was carried out with variations in concentration, namely 8 ppm, 4 ppm, 2 ppm, 1 ppm, and 0.5 ppm. Then DPPH solution was added with a concentration of $40 \mathrm{ppm}$ into each test solution and incubated for $40 \mathrm{~min}$. After incubation, absorbance measurements were carried out with a UV-Visible spectrophotometer on each of the test solutions. The results obtained from testing the antioxidant activity of each ODT extract of the wood extract are shown in table 6.

Table 6: Antioxidant activity results

\begin{tabular}{|c|c|c|c|c|}
\hline Test Sample & Concentration (ppm) & \% Inhibition & Linear regression equation & $\mathrm{IC}_{50}(\mathrm{ppm})$ \\
\hline \multirow{5}{*}{ Extract } & 8 & 71.59734187 & & \multirow{5}{*}{3.757} \\
\hline & 4 & 51.53006809 & & \\
\hline & 2 & 41.43900238 & $Y=5.142 X+30.68$ & \\
\hline & 1 & 35.86020182 & $\mathrm{R}=0.999$ & \\
\hline & 0.5 & 32.69341209 & & \\
\hline \multirow{5}{*}{ Vitamin C } & 3 & 57.42397138 & & \multirow{5}{*}{2.169} \\
\hline & 2.5 & 53.27966607 & & \\
\hline & 2 & 48.70304114 & $Y=9.096 X+30.27$ & \\
\hline & 1 & 38.35718545 & $\mathrm{R}=0.997$ & \\
\hline & 0.5 & 35.49493143 & & \\
\hline \multirow{5}{*}{ Tablet Formula 1} & 8 & 62.86860582 & & \multirow{5}{*}{3.614} \\
\hline & 4 & 55.01905717 & & \\
\hline & 2 & 44.92276830 & $Y=3.129 X+38.63$ & \\
\hline & 1 & 40.70210632 & $\mathrm{R}=0.995$ & \\
\hline & 0.5 & 40.18054162 & & \\
\hline \multirow{5}{*}{ Tablet Formula 2} & 8 & 67.09215442 & & \multirow{5}{*}{3.464} \\
\hline & 4 & 55.19925280 & & \\
\hline & 2 & 43.29078456 & $Y=4.021 X+36.07$ & \\
\hline & 1 & 38.46513076 & $\mathrm{R}=0.989$ & \\
\hline & 0.5 & 40,36108325 & & \\
\hline \multirow{5}{*}{ Tablet Formula 3} & 8 & 82.44175210 & & \multirow{5}{*}{3.173} \\
\hline & 4 & 52.73066170 & & \\
\hline & 2 & 35.07921715 & $Y=6.564 X+29.17$ & \\
\hline & 1 & 32.32095713 & $\mathrm{R}=0.985$ & \\
\hline & 0.5 & 35.49493143 & & \\
\hline
\end{tabular}


From the results of the activity curves of each tested sample obtained a regression equation $y=b x+a$, then entered the value of 50 substituted into $y$, the $\mathrm{IC}_{50}$ value was obtained. $\mathrm{IC}_{50}$ value was the concentration value where the sample was able to reduce DPPH activity by $50 \%$ from the initial concentration. The results of $\mathrm{IC}_{50}$ value calculation showed IC 50 extract value of $3.757 \mathrm{ppm}$, tablet formula 1 was $3.614 \mathrm{ppm}$, tablet formula 2 was at $3.464 \mathrm{ppm}$, tablet formula 3 at $3.173 \mathrm{ppm}$. Vitamin C used as a comparison in this test has an IC 50 value of $2.169 \mathrm{ppm}$. Fig. 1 shows a summary of these IC $\mathrm{C}_{50}$ values.

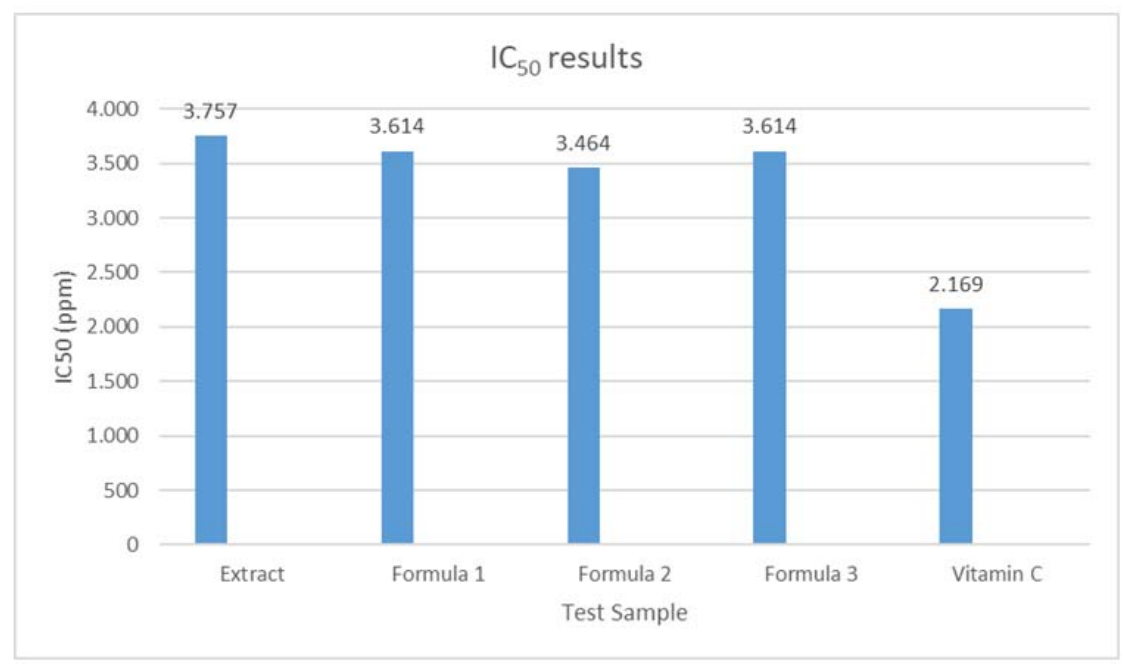

Fig. 1: Summary of IC ${ }_{50}$ obtained from extract and formula compared to vitamin C

In fig. 1 the $\mathrm{IC}_{50}$ value of secang wood extract with the $\mathrm{IC}_{50}$ value of the three ODT formulas of secang wood extract had different values, this was presumably due to the influence of additives in tablet formulations, such as citric acid which increased the antioxidant activity in the formula IC 50 on the extract, because citric acid had activity as an antioxidant. Thus, the $\mathrm{IC}_{50}$ value in all formulas was greater than the extract. A compound was said to be an antioxidant very strong if the $\mathrm{IC}_{50}$ was less than $50 \mathrm{ppm}$. Strong if $\mathrm{IC}_{50}$ values range from $50-100 \mathrm{ppm}$, medium if $\mathrm{IC}_{50}$ values range from $100-150 \mathrm{ppm}$, weak if $\mathrm{IC}_{50}$ values range from $150-200 \mathrm{ppm}$ [38]. Judging from the results obtained, all the ODT formulas of the secang wood extract could be classified in the category of very strong antioxidants because the $\mathrm{IC}_{50}$ value obtained was less than $50 \mathrm{ppm}$. By using DPPH and nitric oxide methods, strong antioxidant properties of $C$. sappan ethyl acetate, methanol, and water extracts were reported by Badami et al. [39-41]. Formulation of Liposome using Sappanwood (Caesalpinia Sappan L.) ethyl acetate fraction as an activate compound had been reported by Noviza et al. [42].

\section{Hedonic taste results}

The preference test was carried out on all ODT extracts of secang wood extract that met the demolition requirements for 30 panelists. Test results for ODT preferences for secang wood extract included levels of preference, taste, after taste, and degree of deformity.

From the results of the test of preference made on the level of preference, there were differences in the level of preference of panelists on the ODT tablets of secang wood extract with differences in the level of preference of the panelists that were evident between the criteria of dislike, rather dislike, neutrality, likes rather like criteria [19]. From the results of the preference tests conducted on after taste, it was found that there were differences in panelists 'judgments about after taste, it was found that there were differences in panelists' assessment of after taste against ODT tablets secang wood extract with differing panelist judgments regarding real after taste between very bitter criteria and criteria not bitter, neutral and rather bitter. From the results of the test conducted on taste, there were differences in panelists 'judgments regarding the taste of ODT tablets secang wood extract with differences in panelists' judgments regarding real taste between the criteria of very sweet, not sweet, very not sweet, with sweet criteria. From the results of the test conducted on the level of rigidity obtained results there were differences in panelists' assessment of the level of rigidity of ODT tablets secang wood extract with different panelist judgments regarding the level of real dexterity between very rigid criteria, not rigorous with criteria neutral, rigid, and rather miserable criteria. Actually, the use of a hedonic test to show a preference for food and medicine had been done by many researchers [43-45].

\section{CONCLUSION}

Based on the results of the printed mass and QC results, the printout of all formulas showed good results. From the three formulas, it can be concluded that secang wood extract (Caesalpinia sappan L.) can be made into ODT preparations that meet the requirements of Indonesian Pharmacopoeia, namely using HPC-H as a variation of concentration masking agent by $4 \%, 4.5 \%$, and $5 \%$. Based on the results of antioxidant testing using the $\mathrm{DPPH}$ method, the $\mathrm{IC}_{50}$ value of secang wood extract was 3.75 ppm, ODT extract of secang wood formula I was $3.173 \mathrm{ppm}$, ODT extract of secang wood formula II was $3.464 \mathrm{ppm}$, ODT extract of wood extract formula III was $3.614 \mathrm{ppm}$, and vitamin $\mathrm{C}$ as a comparison of $2.169 \mathrm{ppm}$. From the $\mathrm{IC}_{50}$ value, it can be concluded that the three formulas belong to the category of antioxidants which are very strong because they have an $\mathrm{IC}_{50}$ value of less than $50 \mathrm{ppm}$. The results of this study suggest that the ODT secang could be as an alternative to well-known antioxidants in the market including enzymes and other substances, such as vitamin C, vitamin $\mathrm{E}$, and beta carotene.

\section{ACKNOWLEDGMENT}

We thank Nurul Nurmalia Dewi for technical support

\section{AUTHORS CONTRIBUTIONS}

All the author have contributed equally

\section{CONFLICT OF INTERESTS}

There is no conflict of interest between authors.

\section{REFERENCES}

1. Singh RP, Sharad S, Kapur S. Free radicals and oxidative stress in neurodegenerative diseases: relevance of dietary antioxidants. JIACM 2004;5:218-25.

2. Scheibmeir HD, Christensen K, Whitaker SH, Jegaethesan J, Clancy R, Pierce JD. A review of free radicals and antioxidants for critical care nurses. Intensive Critical Care Nurs 2005;21:24-8.

3. Vardar Unlu G, Candan F, Sokmen A, Daferera D, Polissiou M, Sokmen M, et al. Antimicrobial and antioxidant activity of the 
essential oil and methanol extracts of Thymus pectinatus fisch. et mey. Var. pectinatus (Lamiaceae). J Agric Food Chem 2003;51:63-7.

4. Saefudin S, Pasaribu G, Sofnie S, Basri E. Effect of sappan wood (Caesalpinia sappan L) extract on blood glucose level in white rats. Indonesian J Forestry Res 2014;1:109-15.

5. Batubara I, Matsunaga T. Use of Indonesian medicinal plants against acne. Rev Agric Sci 2013;1:11-30.

6. Utari FD, Sumirat S, Djaeni M. Antioxidant production from secang wood extract (Caesalpinia sappan L.) using low humidity dryers. J Aplikasi Teknologi Pangan 2017;6:1-4.

7. Kumala S, Yuliani Y, Tulus D. The effect of giving steeping secang wood (Caesalpinia sappan L.) on mouse infected bacteria Escherichia coli. J Farmasi Indonesia 2009;4:188-98.

8. Hirani JJ, Rathod DA, Vadalia KR. Orally disintegrating tablets: a review. Trop J Pharm Res 2009;8:161-72.

9. Fauzi AM. Antioxidant activity of extracts and fractions of secang (Caesalpinia sappan L.) bark extract affected by temperature and $\mathrm{pH}$ using DPPH (Diphenylpicrylhydrazyl) method. Thesis. Bandung: Faculty of Pharmacy, Universitas Padjadjaran; 2012.

10. Badami S, Moorkoth S, Rai SR, Kannan E, Bhojraj S. Antioxidant activity of Caesalpinia sappan heartwood. Biol Pharm Bull 2003;26:1534-7.

11. Kusuma SAF, Mita SR, Firdayani I, Mustarichie R. Study on the antibacterial activity of fruit extracts of klutuk banana (Musa balbisiana Colla) against Shigella dysenteriae ATCC 13313. Asian J Pharm Clin Res 2017;10:220-3.

12. Mustarichie R, Ramdhani D, Iskandar Y. Characteristics and alopecia activity of pakis gajah (Angiopteris evecta (G. Forst) Hoffm.) growing in galunggung mountainside, West Java. Asian J Pharm Clin Res 2017;10:337-40.

13. Departemen Kesehatan RI. Indonesian pharmacopoeia. $4^{\text {th }}$ ed. Jakarta: Departemen Kesehatan RI; 1995.

14. Liang AC, Chen LH. Fast-dissolving intraoral drug delivery systems. Exp Opinion 2001;11:981-6.

15. Nagar P, Singh K, Chauhan I, Verma M, Yasir M, Khan A, et al. Orally disintegrating tablets: formulation, preparation techniques, and evaluation. J Appl Pharm Sci 2011;1:35-45.

16. Badami S, Moorkoth S, Rai SR, Kannan E, Bhojraj S. Antioxidant activity of Caesalpinia sappan heartwood. Biol Pharm Bull 2003;26:1534-7.

17. Nirmal NP, Panichayupakaranant P. Antioxidant, antibacterial, and anti-inflammatory activities of standardized brazilin-rich Caesalpinia sappan extract. Pharm Biol 2014;53:1339-43.

18. Lim Y. Hedonic scaling: a review of methods and theory. Food Quality Preference 2011;22:733-47.

19. Chandra JH. Screening of antimicrobial activity and phytochemical analysis of Caesalpinia sappan L. J Chem Pharm Res 2013;5:171-5.

20. Kaur H, Amini MH, Prabhakar PK, Suttee A, Singh A. Phytochemical screening and antimicrobial activity of Caesalpinia sappan L. Leaves. Int J Pharm Pharm Res 2016;8:1064-9.

21. Srinivasan R, Selvam GG, Karthik S, Mathivanan K, Baskaran R, Karthikeyan M. In vitro antimicrobial activity of Caesalpinia sappan L. Asian Pacific J Trop Biomed 2012;2:S136-S139.

22. Departemen Kesehatan Republik Indonesia. Indonesian Herbal Pharmacopoeia (Indonesian: Farmakope Herbal Indonesia, Edisi I). Jakarta: Departemen Kesehatan Republik Indonesia; 2008.

23. Badan Standarisasi Nasional-BSN, SNI 7387-2009. Jakarta: Heavy Metal Pollution Requirements (in Indonesian); 2009.

24. Regulation of the Minister of Health of Indonesia (Indonesian: Peraturan Menteri Kesehatan Republik Indonesia); 2013.

25. General guidelines for methodologies on research and evaluation of traditional medicine. Geneva. World Health Organization, (WHO/EDM/TRM/2000.1); 2000.

26. Standar Nasional Indonesia (SNI). SNI 7387:2009 Maximum limit of heavy metal contamination in food (Indonesian: Batas Maksimum Cemaran Logam Berat Dalam Makanan). Jakarta: Badan Standardisasi Nasional; 2009.
27. NISSO HPC. High viscosity grade of hydroxypropyl cellulose (HPC-H) for hydrophilic matrix, sustained release formulation. Available from: www.nissoexcipients.com/PDF/Matrix_AppNote_CR2012AAPS. pdf [lAST accessed on 10 Dec 2018]

28. BASF. Kollidon ${ }^{\circledR}$ CL-F. Available from: https:// pharmaceutical.basf.com/en/Drug-Formulation/Kollidon-CLF.html. [Last accessed on 14 Dec 2018].

29. Franc A, Kurhajec S, Pavlokova S, Sabadkova D, Muselik J. Influence of concentration and type of microcrystalline cellulose on the physical properties of tablets containing cornelian cherry fruits. Acta Pharm 2017;67:187-202.

30. Drugs.com. Mannitol. Available from https://www.drugs.com/inactive/mannitol-142.html [Last accessed on10 Jan 2019]

31. Int'l Food Information Council Foundation. Everything You Need to Know About Acesulfame Potassium. Available from: https://www.nutritionexpress.com/article+index/vitamins+su pplements+a-z/showarticle.aspx?id=120 [Last accessed on 05 Jan 2019].

32. Making Cosmetics. Magnesium Stearate, USP. Available from: https://www.makingcosmetics.com/Magnesium-StearateUSP_p_297.html. [Last accessed on 30 Jan 2019]

33. Moncel B. Citric acid and how it's used in your food. Available from: https://www.thespruceeats.com/what-is-citric-acid1328465 [Last accessed on 25 Jan 2019]

34. PubChem. Menthol. Available from: https://pubchem ncbi.nlm.nih.gov/compound/menthol [Last accessed on 25 Jan 2019].

35. Aulton ME. Pharmaceutics: The Science of Dosage Form Design. Longman Group. Churchill Livingstone. New York, Part Four. Dosage Form Design and Manufacture; 2002.

36. Departemen Kesehatan Republik Indonesia. Indonesian Pharmacopoeia (Indonesian: Farmakope Indonesia), 3rd). Jakarta: Departemen Kesehatan Republik Indonesia; 1979.

37. FDA. Guidance for Industry: Orally Disintegrating Tablets; 2008. Available from: www.fda.gov/OHRMS/DOCKTES/ 98fr/FDA-2007-D-0365-gdl.pdf. [Last accessed on 15 Dec 2018].

38. Molyneux P. The use of stable free radical diphenylpicrylhydrazyl (DPPH) for estimating antioxidant activity. Songklanakarin J Sci Technol 2004;26:211-9.

39. Badami S, Moorkoth S, Rammanoharsingh S, Kannan E, Bhojraj S. Antioxidant activity of Caesalpinia sappan heartwood. Biol Pharm Bull 2003;26:1534-7.

40. Nirmal NP, Panichayupakaranant P. Antioxidant, antibacterial, and anti-inflammatory activities of standardized brazilin-rich Caesalpinia sappan extract. J Pharm Biol 2015;53:1339-43.

41. Kimestri $A B$, Indratiningsih I, Widodo W. Microbiological and physicochemical quality of pasteurized milk supplemented with sappan wood extract (Caesalpinia sappan L.), Int Food Res J 2018;25:392-8.

42. Noviza D, Suharti N, Lucida H, Pinto PB. Formulation of liposome using sappanwood (Caesalpinia Sappan L.) ethyl acetate fraction as an activating compound. Orient $\mathrm{J}$ Chem 2018;34:1611-8

43. Febrianto N, Djumarti D, Rizki VM. Development of cardamom herbal coffee beverages: a study of physicochemical characteristics and consumer perception towards sensory properties. Pelita Perkebunan 2015;31:49-58.

44. Ong NE, Djarkasi GSS, Moningka JCS. Consumer level receipt level to sirsak (Annona muricata Linn) leaves tea drink Annona muricata linn (Indonesian: Tingkat Penerimaan Konsumen Terhadap Minuman Herbal Teh Daun Sirsak (Annona muricata Linn.), COCOS; 2016. p. 7.

45. Adinsi L, Akissoe NH, Dalod e-Vieira G, Anihouvi VB, Fliedel G, Mestres C, et al. Sensory evaluation and consumer acceptability of a beverage made from malted and fermented cereal: case ofgowe from Benin. Food Sci Nutr 2015;3:1-9. 